small albums, each containing 12 picture postcards of the natural features and the animal and plant life of the parks and reservations, which should help to spread the knowledge of these magnificent natural areas. It is curious to look upon these activities in Poland and the interest of the State and people in them, and to consider that in our more highly populated land, where the need for protection is greater than in Poland, there is no national park at all, and no State attempt to protect the disappearing land mammals, which were once as varied in kind as those of Poland now are.

\section{Campaign against Noise in New York}

THe New York campaign against noise officially started on October 1, when the Mayor instructed the police to warn offenders and to educate the public without making arrests. The sounding of motor horns between 11 p.m. and 7 a.m. is prohibited, and citizens have been instructed to keep their wireless apparatus at a moderate level. During the first three days, 4,071 warnings were given and 9 summonses were issued. The League for Less Noise has established an office for investigation of complaints, among which motor horns and barking dogs are most frequently mentioned.

\section{Early Frost in 1835 and 1935}

THE note entitled "The Horticultural Society" which appeared in NATURE of October 19, p. 654, refers to the occurrence of a severe frost $\left(27^{\circ} \mathrm{F}\right.$.) on October 20, 1835. Miss E. Armitage, writing from Dadnor, Ross, Herefordshire, remarks that the first frost this season took place on October 20, 1935, with $6^{\circ} \mathrm{F}$. of frost. All tender autumn flowers were killed, and, in particular, some spikes of Kniphofia maxima globosa.

\section{Canadian Earthquake of November I}

From the brief account of it that has so far been received, the earthquake that disturbed eastern Canada and New England shortly after 1 a.m. on November 1 seems to be one of great interest. The epicentre is placed by Canadian seismologists at a point about 250 miles north of Ottawa. The shock was severe throughout the whole northern Abitibi region, and at one place railway lines were torn up and twisted. The earthquake is remarkable, however, not so much for its intensity in the central district, which does not seem to have been unusual, as for its large disturbed area. To the south, it was felt at Chicago, Washington, New York and Boston. The northern limit of the disturbed area may be difficult to trace, as it traverses a sparsely inhabited country, but the total area probably exceeds three-quarters of a million square miles, an amount not often surpassed in North American earthquakes.

\section{Announcements}

The Mackinnon research studentship of the Royal Society has been awarded to Dr. G. W. Brindley, assistant lecturer in physics in the University of Leeds, for his research on X-ray reflections from metals in relation to atomic vibrations.
Mr. P. L. O. GUY has been appointed Director of the British School of Archæology in Jerusalem for the year ending September 30, 1936, on the retirement of Mr. J. W. Crowfoot. Mr. Guy was formerly chief inspector of antiquities for the Government of Palestine, and has had many years experience of field work and excavation. He has already taken up residence in Jerusalem.

Dr. S. I. Levy will deliver the Brauner Memorial Lecture of the Chemical Society on November 14, at 8 , in the rooms of the Society at Burlington House, Piccadilly, London, W.I.

A Discussion on "Some Aspects of the Interaction between Gases and Solids" will be held at the Chemical Society on November 21 at 8 p.m. The discussion will be opened by Prof. E. K. Rideal, who will be followed by contributions from Dr. J. K. Roberts and Dr. R. M. Barrer.

A commitres has been formed under the presidency of J. A. van Heuven in connexion with the celebration of the three hundredth anniversary of the foundation of the University of Utrecht in 1636.

Erratum.--In the last line of the letter by Prof. A. I. Alichanow, A. I. Alichanian and M. S. Kosodaew entitled "Emission of Positrons from a ThoriumActive Deposit" published in NaTURE of September 21 (p. 475), the words "per cent" should have been inserted after " $0 \cdot 02-0 \cdot 03$ ".

Applications are invited for the following appointments, on or before the dates mentioned :

A lecturer in chemistry in the Sir John Cass Technical Institute, Jewry Street, Aldgate, London, E.C.3-The Principal (Nov. 20).

A civilian technical officer in the Admiralty Technical Pool (engineering or physies)-The Secretary of the Admiralty (C.E. Branch), Whitehall, London, S.W.I (Nov. 22).

A principal of the Municipal College, Southend-onSea-The Director of Education (Nov. 25).

A deputy director of agriculture in East Sussex, who will also act as vice-principal of the School of Agriculture, Plumpton-The Director of Agriculture, County Hall, Lewes (Nov. 25).

A lecturer and research assistant in the Department of Higher Degrees and Research in the Institute of Education, Southampton Row, W.C.1 - The Secretary (Nov. 25).

A head of the Physiology Department of the Rowett Research Institute, Bucksburn, Aberdeenshire-The Secretary (Nov. 30).

A director of the Laboratory of Bacteriology and Pathology in Adelaide Hospital, who will also act as Director of Medical Research in the University of Adelaide-The Agent General for South Australia, British Industries House, Marble Arch, London, W.1 (Dec. 12).

A University professor of statistics in the London School of Economics-The Academic Registrar, University of London, S.W.7 (Jan. 31). 